\title{
Active Versus Passive Investing: Evidence From The 2009-2017 Market
}

\author{
Dale Prondzinski \\ Davenport University \\ Mitchell Miller \\ Davenport University
}

The paper explores the research question: During the March 1, 2009 to December 31, 2017 time period, which investment management style, active or passive, produced the better risk-adjusted performance?

The study tested nine hypotheses, derived from the above research question for the period.

The Sharpe composite portfolio performance measure, that combines risk and return into a single value, was used to measure, analyze, and rank risk-adjusted performance.

The study, comprised of 9 statistical tests, found that on a risk-adjusted basis that the active indices (proxies for active management) Sharpe ratios did not significantly exceed the passive indices (proxies for passive management) Sharpe ratios for the period tested.

\section{INTRODUCTION}

Modern Portfolio Theory explores how risk-averse investors construct portfolios to optimize expected returns against market risk and quantifies the benefits of diversification. Two opposing investment management styles, active management and passive management, have debated the superiority of their investment styles in terms of long-term, risk-adjusted performance.

According to Malkiel (2017), a Standard \& Poor's recent report adds support to the growing body of evidence suggesting the superiority of index investment strategies over traditional stock picking. Malkiel asserts that there is no better way than passive investing for individuals to invest in the stock market and save for retirement.

Standard \& Poor's has long served as the scorekeeper and benchmarker, demonstrating the dismal return performance of active portfolio managers. Malkiel reports that during 2016, twothirds of large capitalization U.S. stock active managers underperformed the S\&P large capital index. Over the longer term, the results, as measured by S\&P, were worse; greater than $90 \%$ of active portfolio managers underperformed their benchmark indices over a 15-year period. Evermore compelling are the international market documented findings since 2001; 89\% of active managers had inferior performance compared with their passively managed counterparts. Index funds have also proved their merit in emerging markets, outperforming $90 \%$ of active 
funds. Logic underlying the active versus passive debate remains irrefutable. In a national stock market like the United States, all securities are held by someone; if some investors average better than others, then other investors do worse than the average. Investing must be a zero-sum game; for every winner, there is a corresponding loser.

The costs of active traders, buying and selling securities, makes for a negative-sum game. While the index investor will earn the market return, the active investor must underperform the market by the costs of their management fees, about $1 \%$ a year. Indeed, evidence suggests that active funds underperform index funds by approximately the difference in their costs.

Taxable differences between the treatment of index funds versus active funds indicate that index funds are more tax efficient, given that active funds realize annual taxable capital gains. Thus, the performance gap between passive/index funds and active funds is even larger.

This study seeks to examine the performance of active versus passive management for the time period from March 1, 2009 to December 31, 2017. Section 1 discusses the findings of the previous studies, namely advantages and disadvantages of passive versus active management, while section 2 presents the data, methodology, and the outcomes of the statistical analysis and finally, section 3 provides the concluding remarks and further comments.

\section{LITERATURE REVIEW}

There is a dearth of academic literature examining active versus passive investment strategies between 2009-2017. A literature review reveals that authors have redefined the traditional measures of comparison between active and index funds. New investment products, notably the exchange traded fund, and updated market efficiency arguments and definitions of passive management serve to obscure the foundation of the active versus passive debate.

Clift (2016) opines that the active versus passive management debate is becoming outdated; not irrelevant, just outdated. The author suggests that new strains of investment products, seeking to combine the attributes of active and passive management, will cause financial advisers and investors to adjust their mindset when it comes to asset allocation and selection.

Clift, for example, references the rise of the smart beta ETF as a relatively new product changing the way we think about active and passive management. Clift argues that despite the higher fees associated with smart beta ETFs, some advisers and investors believe that smart beta ETFs are worth having in portfolios.

Blitz (2014) praises passive investing as one of the most successful innovations of modern finance, founded on the capital asset pricing model and the efficient market hypothesis. Blitz acknowledges that active management is a zero-sum game before costs and a negative-sum game after costs. The author clearly acknowledges passive management as an appealing concept, but expressed concerns about 'freeriding behavior' associated with passive investing/investors.

Blitz argues that the existence of a large number of active investors is a necessary requirement for an efficiently functioning market. The author posits that passive investors are free riders, as they do not make an attempt to assess a security's fair value. He concludes that if everyone tried to adopt passive investing, the link between prices and fundamentals would break down, and liquidity would disappear.

Fuller, Han \& Tung (2010) argue that the words "passive" and "passive management" are not being correctly used and that there is no such thing as passive investment management. The authors' perspective is that passive indexing is just another type of active management.

The authors presented a history of indexing and constructed their own index for research purposes. Fuller, Han \& Tung concluded and recommended that the investment community needs to think more about indexing; that indexed returns underperform their market benchmarks; and, perhaps, the most controversial point is that there is no such thing as true passive investing. 
Abrantes (2017) acknowledges that investing momentum has swung in the direction of passive index mutual funds and exchange-traded funds as investors turned their backs on actively managed strategies. Today's estimates suggest that indexing represents more than $40 \%$ of aggregate equity mutual fund assets, twice the level of 10 years ago.

Abrantes believes investors should reject the oversimplified 'active versus passive debate' framework, acknowledging that all investing requires active decision-making. Common among recent 'active versus passive ' researchers and authors is the notion that passive investing isn't actually passive. The author posits that the concept underlying indexing is powerful, but the passive label is misleading and masks the complexities of an investor's decision to index. Passive investing includes a range of active decisions, including:

- Exposure - what exposure would the investor like to own?

- Indexing - should the investor index or not?

- Universe of securities - what specific universe of securities should the investor include in $\mathrm{h} /$ her basket?

- Indexing methodology - should the investor use the capitalization-weighted methodology?

- Fund manager - which index manager to use.

- The vehicle - which vehicle is most appropriate, mutual fund or EFT, for example.

Finally, Abrantes argues that the current 'active versus passive' narrative is too focused on minimizing costs, at the expense of paying attention to other risks.

Ellis (2015), suggesting that active investing has been subjected to increasing abuse, chose to mount a defense of active investing by looking at the broader picture and pointing out the many benefits that skeptics continue missing. Ellis acknowledges that the world of active investing has been under attack in reports for falling short of their benchmarks and that the magnitude of underperformance substantially exceeding the magnitude of outperformance.

Ellis purports that although the cost and fees aspect of the attack against active investing appear compelling, the argument ignores the important social and economic indirect benefits of active investing. The benefits of active management include market efficiency and the societal benefits of active investing at the macro level.

Jones and Wermers' (2011) survey of the literature on the value of active management shows that the average active manager does not outperform, but that a significant minority do add value. The authors suggest that investors may be able to identify superior active managers using public information.

The authors find that, in a mostly efficient market, active returns across managers averages close to zero, net of fees and other expenses, an expected finding in an efficient market. It is thought that competition among active managers drives active risk-adjusted returns toward zero in equilibrium. Jones and Wermers conclude that, by keeping markets efficient, active management provides a critical function in modern capitalist economies: efficient, rational capital allocation improves economic growth and leads to increased wealth for society as a whole.

Bogle (2018) was interviewed by Barron's, and responded to the collective criticisms of indexing. A review of the literature suggests that indexing has destabilized the market. Bogle's response to his critics is that the new vogue of engagement, corporate governance, means indexers such as Vanguard and Blackrock are much less acquiescent to corporate misbehavior than in the past. This will be the age of corporate governance.

According to Bogle, engagement is the role of the indexer; if indexers do not like management, they need to fix the management.

Current academic literature reports that index investors are not allocating capital properly; Bogle's response is that the market has little to do with capital allocation; if someone is buying, someone is selling. Another criticism reported in the literature is that index buying is being done without any concern about return on investment or the efficiency of capital flows. Bogle's reply is that the indexers' influence on the market is overstated because the money is coming out of active funds. While index funds account for $43 \%$ of equity mutual fund assets, their automatic rebalancing makes up just $5 \%$ of all stock trading. 
Active management pundits in the literature point out that as active managers die off, the ability of the market to price publicly traded businesses diminishes. Bogle asserts that the investing industry must be an industry in which marketing takes a back seat to fiduciary responsibility and professionalism. The longer people are aware of cost and realize how long they'll be investing, the more the indexing revolution will increase.

Finally, critics opine that index ownership is concentrated in 3 large companies: Vanguard, Blackrock, and State Street, together making up the largest shareholder of $88 \%$ of the companies in the S\&P 500. Bogle tersely replies that he doesn't see indexing becoming a problem even at $70 \%$ of the market; he says we need more indexing.

\section{DATA AND METHODOLOGY}

The following identifies the research process that was used to test the hypotheses that were derived from the research question.

\section{Research Question}

The study's primary research question was: During the March 1, 2009 to December 31, 2017 time period, which investment management style, active or passive, produced the better risk-adjusted performance?

\section{Research Model and Variables}

Figure 1 presents the research model identified in Miller (2006) and modified in Prondzinski (2010). It details the relationships among the variables and presents a general flow of the study's logic and potential outcomes.

FIGURE 1

RESEARCH MODEL

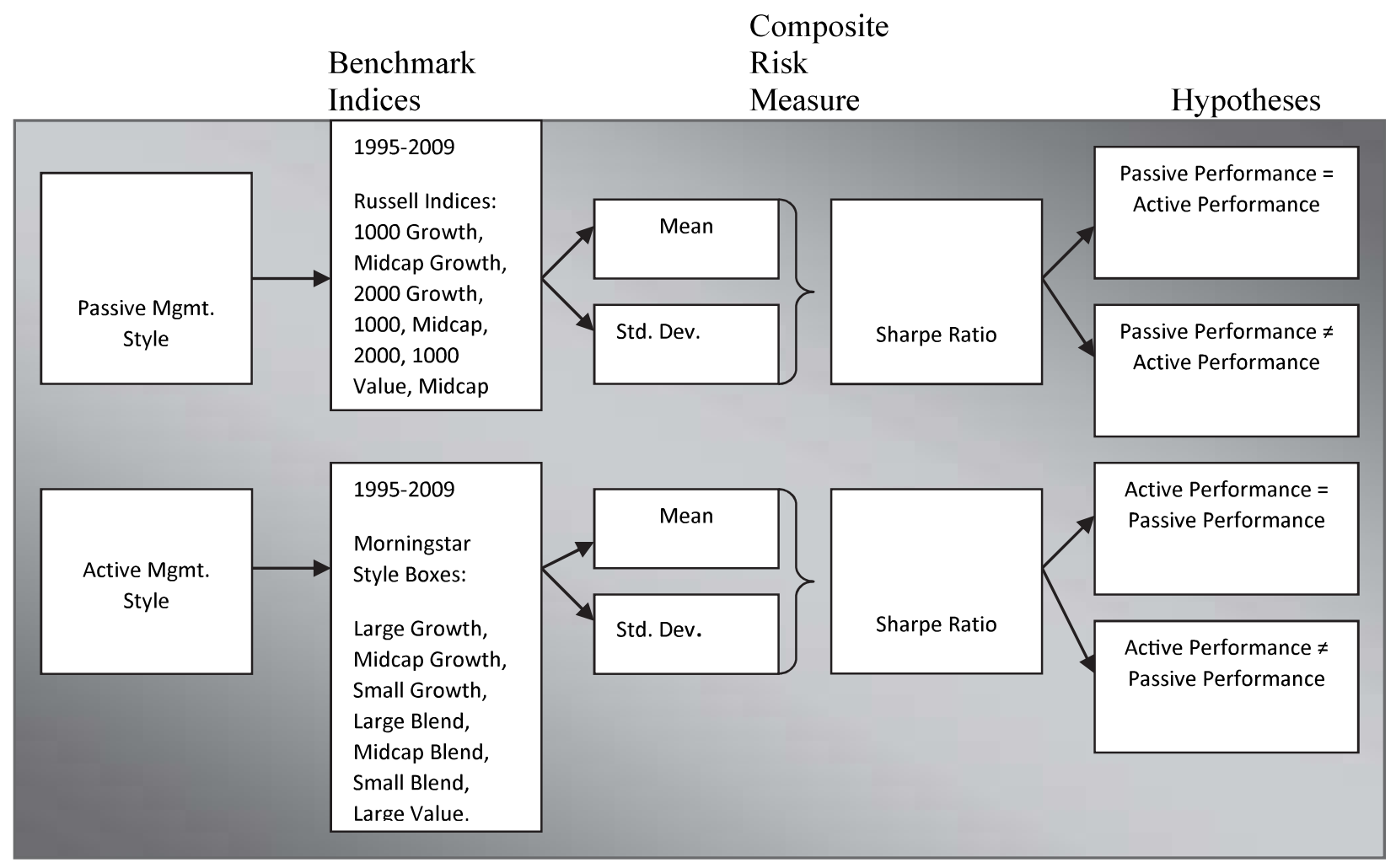


Risk-adjusted returns were measured using the Sharpe composite performance measure, a measure combining risk and return into a single value. The Sharpe ratio was used to compare the passive and active fund performance (Miller, 2006).

\section{Morningstar Style Box}

The Morningstar Style boxes contain the growth, blend, and value investment style. The style includes three category sizes, which are large, mid, and small. The categories are based on market capitalization. The large-cap category stocks account for $70 \%$ of the cumulative market capitalization, while the mid-cap category stocks account for the next $20 \%$ of the market capitalization, and the smallcap category stocks account for the remainder. (Morningstar, 2018)

\section{Hypotheses}

Nine hypotheses, derived from the above research question, to include growth funds, blended funds, and value funds were tested.

\section{Large Growth Fund/Index}

$\mathrm{H}_{0}$ : For the time period March 1, 2009 to December 31, 2017, the actively managed large growth investment category Sharpe ratio is not significantly greater than the passively managed Russell 1000 Growth Index Sharpe ratio.

$\mathrm{H} 1_{\mathrm{a}}$ : For the time period March 1, 2009 to December 31, 2017, the actively managed large growth investment category Sharpe ratio is significantly greater than the passively managed Russell 1000 Growth Index Sharpe ratio.

\section{Midcap Growth Fund/Index}

H20: For the time period March 1, 2009 to December 31, 2017, the actively managed midcap growth investment category Sharpe ratio is not significantly greater than the passively managed Russell Midcap Growth Index Sharpe ratio.

H2a: For the time period March 1, 2009 to December 31, 2017, the actively managed midcap growth investment category Sharpe ratio is significantly greater than the passively managed Russell Midcap Growth Index Sharpe ratio.

\section{Small Growth Fund/Index.}

H30: For the time period March 1, 2009 to December 31, 2017, the actively managed small growth investment category Sharpe ratio is not significantly greater than the passively managed Russell 2000 Growth Index Sharpe ratio.

H3a: For the time period March 1, 2009 to December 31, 2017, the actively managed small growth investment category Sharpe ratio is significantly greater than the passively managed Russell 2000 Growth Index Sharpe ratio.

\section{Large Blend Fund/Index.}

H40: For the time period March 1, 2009 to December 31, 2017, the actively managed large blend investment category Sharpe ratio is not significantly greater than the passively managed Russell 1000 Index Sharpe ratio.

H4a: For the time period March 1, 2009 to December 31, 2017, the actively managed large blend investment category Sharpe ratio is significantly greater than the passively managed Russell 1000 Index Sharpe ratio.

\section{Midcap Blend Fund/Index.}

H50: For the time period March 1, 2009 to December 31, 2017, the actively managed midcap blend investment category Sharpe ratio is not significantly greater than the passively managed Russell Midcap Index Sharpe ratio. 
H5a: For the time period March 1, 2009 to December 31, 2017, the actively managed midcap blend investment category Sharpe ratio is significantly greater than the passively managed Russell Midcap Index Sharpe ratio.

Small Blend Fund/Index.

H60: For the time period March 1, 2009 to December 31, 2017, the actively managed small blend investment category Sharpe ratio is not significantly greater than the passively managed Russell 2000 Index Sharpe ratio.

H6a: For the time period March 1, 2009 to December 31, 2017, the actively managed small blend investment category Sharpe ratio is significantly greater than the passively managed Russell 2000 Index Sharpe ratio.

\section{Large Value Fund/Index.}

H70: For the time period March 1, 2009 to December 31, 2017, the actively managed large value investment category Sharpe ratio is not significantly greater than the passively managed Russell 1000 Value Index Sharpe ratio.

H7a: For the time period March 1, 2009 to December 31, 2017, the actively managed large value investment category Sharpe ratio is significantly greater than the passively managed Russell 1000 Value Index Sharpe ratio.

\section{Midcap Value Fund/Index.}

H80: For the time period March 1, 2009 to December 31, 2017, the actively managed midcap value investment category Sharpe ratio is not significantly greater than the passively managed Russell Midcap Value Index Sharpe ratio.

H8a: For the time period March 1, 2009 to December 31, 2017, the actively managed midcap value investment category Sharpe ratio is significantly greater than the passively managed Russell Midcap Value Index Sharpe ratio.

\section{Small Value Fund/Index.}

H90: For the time period March 1, 2009 to December 31, 2017, the actively managed small value investment category Sharpe ratio is not significantly greater than the passively managed Russell 2000 Value Index Sharpe ratio.

H9a: For the time period March 1, 2009 to December 31, 2017, the actively managed small value investment category Sharpe ratio is significantly greater than the passively managed Russell 2000 Value Index Sharpe ratio.

\section{Sample and Population}

Morningstar Direct was the database used for the research. A comparison was made using the Morningstar style boxes consisting of nine mutual fund classifications (see Table 1): large growth; midcap growth; small growth; large blend; midcap blend; small blend; large value; midcap value; and small value as the variable for active investment versus the passive benchmarks identified as follows: Russell 1000 Growth Index (large growth); Russell Midcap Growth Index (midcap growth); Russell 2000 Growth Index (small growth); Russell 1000 Index (large blend); Russell Midcap Index (midcap blend); Russell 2000 Index (small blend); Russell 1000 Value Index (large value); Russell Midcap Value Index (midcap value); and Russell 2000 Value Index (small value). 
TABLE 1

MORNINGSTAR STYLE BOXES AND CORRESPONDING BENCHMARK INDEX

\begin{tabular}{|c|c|c|}
\hline & Active Index & Benchmark Index \\
\hline 1. & Large Growth & Russell 1000 Growth Index \\
\hline 2. & Midcap Growth & Russell Midcap Growth Index \\
\hline 3. & Small Growth & Russell 2000 Growth Index \\
\hline 4. & Large Blend & Russell 1000 Index \\
\hline 5. & Midcap Blend & Russell Midcap Index \\
\hline 6. & Small Blend & Russell 2000 Index \\
\hline 7. & Large Value & Russell 1000 Value Index \\
\hline 8. & Midcap Value & Russell Midcap Value Index \\
\hline 9. & Small Value & Russell 2000 Value Index \\
\hline
\end{tabular}

\section{Data Collection Methods}

Secondary data were collected and analyzed from the Morningstar Direct database. The database query used was open end fund, Morningstar category, domicile (U.S.), and index fund (no). All open end investments were included in the search to eliminate survivorship bias. The search yielded the following number of funds for each Morningstar investment category: large growth $(4,163)$, midcap growth $(1,879)$, small growth $(1,917)$, large blend $(3,698)$, midcap blend $(908)$, small blend $(1,369)$, large value $(3,047)$, midcap value (881) and small value (904).

Daily returns were extracted from the Morningstar Direct database for each fund in the investment category. The daily fund returns were then averaged using the Microsoft Excel computer program to determine a category average for each day within the specific year of the study. The calculations yielded 3,228 daily data points for each investment category.

Standard deviations, the average portfolio returns, and the average risk-free returns were then calculated with the Microsoft Excel computer program using five daily data points. The Bank of America Merrill Lynch 3-month daily Treasury bill returns were used as the risk-free rate to compute the average risk-free returns. These figures were then used to calculate the Sharpe Ratio. The computations yielded 646 data points for all categories.

Daily data points were extracted and used for each set of paired index comparisons. The daily data points of paired indices were exported into the Microsoft Excel computer program spreadsheet. The means, variances, and related risk-adjusted measures of each of the paired indices were calculated, compared, and analyzed.

\section{Data Analysis Methods}

Data analysis was conducted using statistical analyses and hypothesis testing. Each data set was tested for normality, using the Kolmogorov-Smirnov test (KS-test) in the Statistical Package for the Social Sciences (SPSS).

If data were normal, the $F$-tests for two samples for variance were used to test for significant differences between the means of passive indices and active indices for the different investment categories (Miller, 2006). The null hypothesis was rejected if the estimated F-value was larger than the Fcritical value and/or a p-value was less than 0.05 .

If the data were not normal, then non-parametric statistical tests would be conducted. 


\section{RESULTS}

The following details the results and findings of the study's hypotheses tests based on the data extracted from the Morningstar Direct Database and thereby address the study's research question. The findings of the research are presented in the order in which the hypotheses have been stated. The research question for the study was: During the time period March 1, 2009 to December 31, 2017, which investment management style, active or passive, produced the better risk-adjusted performance? Nine hypotheses, derived from the above research question, were tested.

\section{Demographics of the Population}

Secondary data were collected and analyzed from the Morningstar Direct database. The database query used was open end fund, Morningstar category, domicile (U.S.), and index fund (no). All open end investments were included in the search to eliminate survivorship bias. The search yielded the following number of funds for each Morningstar investment category: large growth $(4,163)$, midcap growth $(1,879)$, small growth $(1,917)$, large blend $(3,698)$, midcap blend $(908)$, small blend $(1,369)$, large value $(3,047)$, midcap value (881) and small value (904). The daily returns of each fund in the category where then added together to compute a daily category average.

\section{Descriptive Statistics}

Table 2 (Hypothesis 1) provides a comparison of the mean daily returns, mean daily Sharpe Ratios, the standard deviations, and the variances for the large growth fund category against the passively managed Russell 1000 Growth Index for the time period of the study. The mean daily return for the period was lower for the large growth category return at 0.047 as compared to the passive Russell 1000 Growth Index return of 0.052 .

The mean daily Sharpe Ratio for the period for the large growth category was lower at 0.122 than the passively managed Russell 1000 Growth Index at 0.137 . The standard deviations tended to be very close arithmetically while the variance was higher for the passive index. The large growth fund category's standard deviation was 0.512 and the variance was 0.217 while the passive index's was 0.516 and 0.266 , respectively.

TABLE 2

NUMBER OF FUNDS, DAILY RETURNS, SHARPE RATIOS, STANDARD DEVIATIONS, VARIANCES, AND P-VALUES: LARGE GROWTH VERSUS RUSSELL 1000 GROWTH INDEX

\begin{tabular}{|cccccc|}
\hline $\begin{array}{c}\text { Number/Returns/Ratios/Standard } \\
\text { Deviation/Variance/P-Value }\end{array}$ & $\begin{array}{c}\text { Hypothesis } \\
\text { Number }\end{array}$ & Time Period & Active Index & Passive Index & P-Value \\
\hline & $\mathrm{H} 1_{0}$ & $2009-2017$ & Large Growth & $\begin{array}{c}\text { Russell 1000 } \\
\text { Growth }\end{array}$ & \\
\hline Number of Funds Within Category & & & 4163 & 542 \\
\hline Mean Daily Return & & 0.047 & 0.052 \\
\hline Mean Daily Sharpe Ratio per Week & & 0.122 & 0.137 \\
\hline Standard Deviation & & 0.512 & 0.516 \\
\hline Variance & & 0.217 & 0.266 & \\
\hline $\mathrm{P}(\mathrm{F}<=$ f) one-tailed test & & & & 0.417 \\
\hline
\end{tabular}

Table 3 (Hypothesis 2) provides a comparison of the mean daily returns, mean daily Sharpe Ratios, the standard deviations, and the variances for the midcap growth fund category against the passively managed Russell Midcap Growth Index for the time period of the study. The mean daily return for the 
period was slightly lower for the actively managed funds than the passive index proxy, the Russell Midcap Growth Index. The difference between mean daily returns was 0.006.

The mean daily Sharpe Ratio for the period for the midcap growth category was higher than the passively managed Russell Midcap Growth Index where the midcap growth category Sharpe Ratio was 0.116 as compared to passive index ratios of 0.129 . The standard deviations and the variances again tended to be very close arithmetically. The midcap growth fund category's standard deviation was 0.512 and the variance was 0.263 while the passive index's was 0.513 and 0.263 , respectively.

TABLE 3

NUMBER OF FUNDS, DAILY RETURNS, SHARPE RATIOS, STANDARD DEVIATIONS, VARIANCES, AND P-VALUES: MIDCAP GROWTH VERSUS RUSSELL MIDCAP GROWTH INDEX

\begin{tabular}{|cccccc|}
\hline $\begin{array}{c}\text { Number/Returns/Ratios/Standard } \\
\text { Deviation/Variance/P-Value }\end{array}$ & $\begin{array}{c}\text { Hypothesis } \\
\text { Number }\end{array}$ & $\begin{array}{c}\text { Time } \\
\text { Period }\end{array}$ & $\begin{array}{c}\text { Active Index } \\
\text { Passive Index }\end{array}$ & P-Value \\
\hline Number of Funds Within Category & & & $\begin{array}{c}\text { Midcap } \\
\text { Growth }\end{array}$ & $\begin{array}{c}\text { Russell Midcap } \\
\text { Growth }\end{array}$ \\
\hline Mean Daily Return & & 1879 & 415 \\
\hline Mean Daily Sharpe Ratio per Week & & 0.048 & 0.054 \\
\hline Standard Deviation & & 0.116 & 0.129 \\
\hline Variance & & 0.512 & 0.513 \\
\hline $\mathrm{P}(\mathrm{F}<=$ f) one-tailed test & 0.263 & 0.263 & \\
\hline
\end{tabular}

Table 4 (Hypothesis 3) provides a comparison of the mean daily returns, mean daily Sharpe Ratios, the standard deviations, and the variances for the small growth fund category against the passively managed Russell 2000 Growth Index for the time period of the study. The mean daily return of 0.055 for the period was greater for the passive Russell 1000 Growth Index as compared to the small growth category return of 0.051 .

The mean daily Sharpe Ratio for the period for the small growth category was higher than the passively managed Russell 2000 Growth Index as the small growth category Sharpe Ratio was 0.108 as compared to 0.106 . The standard deviations and the variances tended to be very close arithmetically. The small growth fund category's standard deviation was 0.526 and the variance was 0.277 while the passive index's was 0.518 and 0.268 , respectively. 
TABLE 4

NUMBER OF FUNDS, DAILY RETURNS, SHARPE RATIOS, STANDARD DEVIATIONS, VARIANCES, AND P-VALUES: SMALL GROWTH VERSUS RUSSELL 2000 GROWTH INDEX

\begin{tabular}{|cccccc|}
\hline $\begin{array}{c}\text { Number/Returns/Ratios/Standard } \\
\text { Deviation/Variance/P-Value }\end{array}$ & $\begin{array}{c}\text { Hypothesis } \\
\text { Number }\end{array}$ & $\begin{array}{c}\text { Time } \\
\text { Period }\end{array}$ & Active Index & Passive Index & P-Value \\
\hline Number of Funds Within Category & $\mathrm{H} 3_{0}$ & $2009-2017$ & Small Growth & $\begin{array}{c}\text { Russell } 2000 \\
\text { Growth }\end{array}$ \\
\hline Mean Daily Return & & 1917 & 1221 \\
\hline Mean Daily Sharpe Ratio per Week & & 0.051 & 0.055 \\
\hline Standard Deviation & & 0.108 & 0.106 \\
\hline Variance & & 0.526 & 0.518 \\
\hline $\mathrm{P}(\mathrm{F}<=\mathrm{f})$ one-tailed test & 0.277 & 0.268 & \\
\hline
\end{tabular}

Table 5 (Hypothesis 4) provides a comparison of the mean daily returns, mean daily Sharpe Ratios, the standard deviations, and the variances for the large blend fund category against the passively managed Russell 1000 Index for the time period of the study. The mean daily return for the period was larger for the passive Russell 1000 Index at 0.048 as compared to the large blend category return of 0.045 .

The mean daily Sharpe Ratio for the period for the large blend category was lower than the passively managed Russell 1000 Index where the large blend category Sharpe Ratio was 0.119 as compared to 0.126 for the passive index. The standard deviations and the variances tended to be very close arithmetically as there was no difference between the two categories.

TABLE 5

NUMBER OF FUNDS, DAILY RETURNS, SHARPE RATIOS, STANDARD DEVIATIONS, VARIANCES, AND P-VALUES: LARGE BLEND VERSUS RUSSELL 1000 INDEX

\begin{tabular}{|cccccc|}
\hline $\begin{array}{c}\text { Number/Returns/Ratios/Standard } \\
\text { Deviation/Variance/P-Value }\end{array}$ & $\begin{array}{c}\text { Hypothesis } \\
\text { Number }\end{array}$ & $\begin{array}{c}\text { Time } \\
\text { Period }\end{array}$ & Active Index & $\begin{array}{c}\text { Passive } \\
\text { Index }\end{array}$ & P-Value \\
\hline & $\mathrm{H} 4_{0}$ & $2009-2017$ & Large Blend & Russell 1000 & \\
\hline Number of Funds Within Category & & & 3698 & 985 \\
\hline Mean Daily Return & & & 0.045 & 0.048 \\
\hline Mean Daily Sharpe Ratio per Week & & 0.119 & 0.126 \\
\hline Standard Deviation & & 0.504 & 0.504 \\
\hline Variance & & 0.254 & 0.254 & \\
\hline $\mathrm{P}(\mathrm{F}<=$ f) one-tailed test & & & & 0.491 \\
\hline
\end{tabular}

Table 6 (Hypothesis 5) provides a comparison of the mean daily returns, mean daily Sharpe Ratios, the standard deviations, and the variances for the midcap blend fund category against the passively managed Russell Midcap Index for the time period of the study. The mean daily return for the period was larger for the passive Russell Midcap Index at 0.054 as compared to the midcap blend category return of 0.047 .

The mean daily Sharpe Ratio for the period for the midcap blend category was lower than the passively managed Russell Midcap Index, where the midcap blend category Sharpe Ratio was 0.114 as compared to 0.123 for the passive index. The standard deviations and the variances tended to be very close arithmetically. The standard deviation during the time period was 0.518 for the midcap blend 
category while 0.514 for the passive index. The variance was 0.268 for the midcap blend category and 0.264 for the passive index.

TABLE 6

NUMBER OF FUNDS, DAILY RETURNS, SHARPE RATIOS, STANDARD DEVIATIONS, VARIANCES, AND P-VALUES: MIDCAP BLEND VERSUS RUSSELL MIDCAP INDEX

\begin{tabular}{|cccccc|}
\hline $\begin{array}{c}\text { Number/Returns/Ratios/Standard } \\
\text { Deviation/Variance/P-Value }\end{array}$ & $\begin{array}{c}\text { Hypothesis } \\
\text { Number }\end{array}$ & Time Period & Active Index & $\begin{array}{c}\text { Passive } \\
\text { Index }\end{array}$ & P-Value \\
\hline & $\mathrm{H} 5_{0}$ & $2009-2017$ & Midcap Blend & $\begin{array}{c}\text { Russell } \\
\text { Midcap }\end{array}$ \\
\hline Number of Funds Within Category & & & 908 & 791 \\
\hline Mean Daily Return & & 0.047 & 0.054 \\
\hline Mean Daily Sharpe Ratio per Week & & 0.114 & 0.123 \\
\hline Standard Deviation & & 0.518 & 0.514 \\
\hline Variance & & 0.268 & 0.264 & \\
\hline $\mathrm{P}(\mathrm{F}<=\mathrm{f})$ one-tailed test & & & & 0.425 \\
\hline
\end{tabular}

Table 7 (Hypothesis 6) provides a comparison of the mean daily returns, mean daily Sharpe Ratios, the standard deviations, and the variances for the small blend fund category against the passively managed Russell 2000 Index for the time period of the study. The mean daily return for the period was smaller for the small blend category at 0.050 as compared to the passive Russell 2000 Index return of 0.053 .

The mean daily Sharpe Ratio for the period for the small blend category was higher than the passively managed Russell 2000 Index. The standard deviations and the variances tended to be very close arithmetically. The standard deviation during the time period was 0.521 for the small blend category while at 0.518 for the passive index. The variance was 0.271 for the small blend category and 0.268 for the passive index.

TABLE 7

NUMBER OF FUNDS, DAILY RETURNS, SHARPE RATIOS, STANDARD DEVIATIONS, VARIANCES, AND P-VALUES: SMALL BLEND VERSUS RUSSELL 2000 INDEX

\begin{tabular}{|cccccc|}
\hline $\begin{array}{c}\text { Number/Returns/Ratios/Standard } \\
\text { Deviation/Variance/P-Value }\end{array}$ & $\begin{array}{c}\text { Hypothesis } \\
\text { Number }\end{array}$ & $\begin{array}{c}\text { Time } \\
\text { Period }\end{array}$ & Active Index & Passive Index & P-Value \\
\hline & $\mathrm{H} 6_{0}$ & $2009-2017$ & Small Blend & Russell 2000 & \\
\hline Number of Funds Within Category & & 1369 & 2000 \\
\hline Mean Daily Return & & 0.050 & 0.053 \\
\hline Mean Daily Sharpe Ratio per Week & & 0.102 & 0.101 \\
\hline Standard Deviation & & 0.521 & 0.518 \\
\hline Variance & & 0.271 & 0.268 & \\
\hline $\mathrm{P}(\mathrm{F}<=\mathrm{f})$ one-tailed test & & & & 1.138 \\
\hline
\end{tabular}

Table 8 (Hypothesis 7) provides a comparison of the mean daily returns, mean daily Sharpe Ratios, the standard deviations, and the variances for the large value fund category against the passively managed Russell 1000 Value Index for the time period of the study. The mean daily return for the period was larger for the passive Russell 1000 Value Index at 0.048 as compared to the large value category return of 0.044 . 
The mean daily Sharpe Ratio for the period for the large value category was higher than the passively managed Russell 1000 Value Index, where the large value category Sharpe Ratio was 0.111 as compared to 0.108 for the passive index. The standard deviations and the variances tended to be very close arithmetically. The large value fund category's standard deviation was 0.505 and the variance was 0.255 while the passive index's was 0.500 and 0.250 , respectively.

TABLE 8

NUMBER OF FUNDS, DAILY RETURNS, SHARPE RATIOS, STANDARD DEVIATIONS, VARIANCES, AND P-VALUES: LARGE VALUE VERSUS RUSSELL 1000 VALUE INDEX

\begin{tabular}{|cccccc|}
\hline $\begin{array}{c}\text { Number/Returns/Ratios/Standard } \\
\text { Deviation/Variance/P-Value }\end{array}$ & $\begin{array}{c}\text { Hypothesis } \\
\text { Number }\end{array}$ & $\begin{array}{c}\text { Time } \\
\text { Period }\end{array}$ & $\begin{array}{c}\text { Active } \\
\text { Index }\end{array}$ & Passive Index & P-Value \\
\hline & $\mathrm{H} 7_{0}$ & $2009-2017$ & $\begin{array}{c}\text { Large } \\
\text { Value }\end{array}$ & $\begin{array}{c}\text { Russell 1000 } \\
\text { Value }\end{array}$ \\
\hline Number of Funds Within Category & & & 3047 & 728 \\
\hline Mean Daily Return & & 0.044 & 0.048 \\
\hline Mean Daily Sharpe Ratio per Week & & 0.111 & 0.108 \\
\hline Standard Deviation & & 0.505 & 0.500 \\
\hline Variance & & 0.255 & 0.250 & \\
\hline $\mathrm{P}(\mathrm{F}<=$ f) one-tailed test & & & & 0.411 \\
\hline
\end{tabular}

Table 9 (Hypothesis 8) provides a comparison of the mean daily returns, mean daily Sharpe Ratios, the standard deviations, and the variances for the midcap value fund category against the passively managed Russell Midcap Value Index for the time period of the study. The mean daily return for the period was larger for the passive Russell Midcap Value Index at 0.054 as compared to the midcap value category return of 0.049 .

The mean daily Sharpe Ratio for the period for the midcap value category was lower than the passively managed Russell Midcap Index, where the midcap value category Sharpe Ratio was 0.111 as compared to 0.0115 for the passive index. The standard deviations and the variances tended to be very close arithmetically. The midcap value fund category's standard deviation was 0.522 and the variance was 0.272 while the passive index's was 0.520 and 0.271 , respectively.

TABLE 9

NUMBER OF FUNDS, DAILY RETURNS, SHARPE RATIOS, STANDARD DEVIATIONS, VARIANCES, AND P-VALUES: MIDCAP VALUE VERSUS RUSSELL MIDCAP VALUE INDEX

\begin{tabular}{|cccccc|}
\hline $\begin{array}{c}\text { Number/Returns/Ratios/Standard } \\
\text { Deviation/Variance/P-Value }\end{array}$ & $\begin{array}{c}\text { Hypothesis } \\
\text { Number }\end{array}$ & $\begin{array}{c}\text { Time } \\
\text { Period }\end{array}$ & Active Index & Passive Index & P-Value \\
\hline & $\mathrm{H} 8_{0}$ & $\begin{array}{c}2009- \\
2017\end{array}$ & Midcap Value & $\begin{array}{c}\text { Russell Midcap } \\
\text { Value }\end{array}$ & \\
\hline Number of Funds Within Category & & & 881 & 595 \\
\hline Mean Daily Return & & 0.049 & 0.054 \\
\hline Mean Daily Sharpe Ratio per Week & & 0.111 & 0.115 \\
\hline Standard Deviation & & 0.522 & 0.520 \\
\hline Variance & & 0.272 & 0.271 & \\
\hline $\mathrm{P}(\mathrm{F}<=$ f) one-tailed test & & & & 0.468 \\
\hline
\end{tabular}


Table 10 (Hypothesis 9) provides a comparison of the mean daily returns, mean daily Sharpe Ratios, the standard deviations, and the variances for the small value fund category against the passively managed Russell 2000 Value Index for the time period of the study. The mean daily return for the period was larger for the passive Russell 2000 Value Index at 0.051 as compared to the small value category return of 0.050 .

The mean daily Sharpe Ratio for the period for the small value category was higher than the passively managed Russell 2000 Value Index, where the small value category Sharpe Ratio was 0.096 as compared to 0.091 for the passive index. . The standard deviations and the variances tended to be very close arithmetically. These standard deviations during the time period were 0.521 for the small value category while they were also 0.521 for the passive index. The variances were 0.272 for the small value category and 0.272 for the passive index.

TABLE 10

NUMBER OF FUNDS, DAILY RETURNS, SHARPE RATIOS, STANDARD DEVIATIONS, VARIANCES, AND P-VALUES: SMALL VALUE VERSUS RUSSELL 2000 VALUE INDEX

\begin{tabular}{|cccccc|}
\hline $\begin{array}{c}\text { Number/Returns/Ratios/Standard } \\
\text { Deviation/Variance/P-Value }\end{array}$ & $\begin{array}{c}\text { Hypothesis } \\
\text { Number }\end{array}$ & $\begin{array}{c}\text { Time } \\
\text { Period }\end{array}$ & Active Index & Passive Index & P-Value \\
\hline & $\mathrm{H} 9_{0}$ & $2009-2017$ & Small Value & $\begin{array}{c}\text { Russell } 2000 \\
\text { Value }\end{array}$ \\
\hline Number of Funds Within Category & & & 904 & 1356 \\
\hline Mean Daily Return & & 0.050 & 0.051 \\
\hline Mean Daily Sharpe Ratio per Week & & 0.096 & 0.091 \\
\hline Standard Deviation & & 0.521 & 0.521 \\
\hline Variance & & 0.272 & 0.272 & \\
\hline $\mathrm{P}(\mathrm{F}<=\mathrm{f})$ one-tailed test & & & 0.496 \\
\hline
\end{tabular}

\section{Results of the Study}

Large Growth Fund/Index (Hypothesis 1)

Weekly Sharpe ratios were calculated from daily returns for the Russell 1000 Growth Index and the Morningstar large growth investment category for the period March 1, 2009 to December 31, 2017 representing 646 periods.

Appendix A shows the Kolmogorov Smirnov-test (KS-test) for normality and the F-test two-samples for variance results for the time period addressed in the study. The KS-test was normal for the period; therefore, the F-test two samples for variance was conducted as identified in the study's methodology section. The F-value for the period was 0.984 . The corresponding p-value for the period was 0.417 . Given these results, the null hypothesis of the time period was retained. That is, the actively managed large growth investment category Sharpe ratio was not significantly greater than the passively managed Russell 1000 Growth Index Sharpe ratio for the period.

\section{Midcap Growth Fund/Index (Hypothesis 2)}

Weekly Sharpe ratios were calculated from daily returns for the Russell Midcap Growth Index and the Morningstar midcap growth investment category for the period March 1, 2009 to December 31, 2017 representing 646 periods.

Appendix B shows the KS-test for normality and the F-test two-samples for variance results for the time period addressed in the study. The KS-test was normal for the period; therefore, the F-test two samples for variance was conducted as identified in the study's methodology section. The F-value for the period was 0.999 . The corresponding p-value for the period was 0.496 . Given these results, the null hypothesis for the time period was retained. Therefore, the actively managed midcap growth investment 
category Sharpe ratio was not significantly greater than the passively managed Russell Midcap Growth Index Sharpe ratio for the time period.

\section{Small Growth Fund/Index (Hypothesis 3)}

Weekly Sharpe ratios were calculated from daily returns for the Russell 2000 Growth Index and the Morningstar small growth investment category for the period March 1, 2009 to December 31, 2017 representing 646 periods.

Appendix $\mathrm{C}$ shows the KS-test for normality and the F-test two-samples for variance results for the time period addressed in the study. The KS-test was normal for the period; therefore, the F-test two samples for variance was conducted as identified in the study's methodology section. The F-value for the period was 1.031. The corresponding p-value for the period was 0.347 . Given these results, the null hypothesis for the time period was retained. Therefore, the actively managed small growth investment category Sharpe ratio was not significantly greater than the passively managed Russell 2000 Growth Index Sharpe ratio for the time period.

\section{Large Blend Fund/Index (Hypothesis 4)}

Weekly Sharpe ratios were calculated from daily returns for the Russell 1000 Index and the Morningstar large blend investment category for the period March 1, 2009 to December 31, 2017 representing 646 periods.

Appendix D shows the KS-test for normality and the F-test two-samples for variance results for the time period addressed in the study. The KS-test was normal for the period; therefore, the F-test two samples for variance was conducted as identified in the study's methodology section. The F-value for the period was 1.002 . The corresponding p-values for the period was 0.491 . Given these results, the null hypothesis for the time period was retained. Therefore, the actively managed large blend investment category Sharpe ratio was not significantly greater than the passively managed Russell 1000 Index Sharpe ratio for the five periods.

\section{Midcap Blend Fund/Index (Hypothesis 5)}

Weekly Sharpe ratios were calculated from daily returns for the Russell Midcap Blend Index and the Morningstar midcap blend investment category for the period March 1, 2009 to December 31, 2017 representing 646 periods.

Appendix E shows the KS-test for normality and the F-test two-samples for variance results for the five periods addressed in the study. The KS-test was normal for the period; therefore, the F-test two samples for variance was conducted as identified in the study's methodology section. The F-values for the period was 1.015. The corresponding p-value for the period was 0.425 . Given these results, the null hypothesis time period was retained. Therefore, the actively managed midcap blend investment category Sharpe ratio was not significantly greater than the passively managed Russell Midcap Blend Index Sharpe ratio for the time period.

\section{Small Blend Fund/Index (Hypothesis 6)}

Weekly Sharpe ratios were calculated from daily returns for the Russell 2000 Index and the Morningstar small blend investment category for the period March 1, 2009 to December 31, 2017 representing 646 periods.

Appendix $\mathrm{F}$ shows the KS-test for normality and the F-test two-samples for variance results for the time period addressed in the study. The KS-test was normal for the period; therefore, the F-test two samples for variance was conducted as identified in the study's methodology section. The F-value for the period was 1.012. The corresponding p-value for the period was 0.439 . Given these results, the null hypothesis was retained. Therefore, the actively managed small blend investment category Sharpe ratio was not significantly greater than the passively managed Russell 2000 Index Sharpe ratio for the time period. 


\section{Large Value Fund/Index (Hypothesis 7)}

Weekly Sharpe ratios were calculated from daily returns for the Russell 1000 Value Index and the Morningstar large value investment category for the period March 1, 2009 to December 31, 2017 representing 646 periods.

Appendix G shows the KS-test for normality and the F-test two-samples for variance results for the period addressed in the study. The KS-test was normal for the period; therefore, the F-test two samples for variance was conducted as identified in the study's methodology section. The F-value for the period was 1.018 . The corresponding p-value for the period was 0.411 . Given these results the null hypothesis for the period was retained. Therefore, the actively managed large value investment category Sharpe ratios were not significantly greater than the passively managed Russell 1000 Value Index Sharpe ratios for the time period.

\section{Midcap Value Fund/Index (Hypothesis 8)}

Weekly Sharpe ratios were calculated from daily returns for the Russell Midcap Value Index and the Morningstar midcap value investment category for the period March 1, 2009 to December 31, 2017 representing 646 periods.

Appendix H shows the KS-test for normality and the F-test two-samples for variance results for the period addressed in the study. The KS-test was normal for the period; therefore, the F-test two samples for variance was conducted as identified in the study's methodology section. The F-value for the period was 1.006 . The corresponding p-value for the period was 0.468 . Given these results, the null hypothesis for the period was retained. Hence, risk-adjusted returns for active mutual fund management were not significantly greater than risk-adjusted returns for passive mutual fund management for the midcap value funds for the time period.

\section{Small Value Fund/Index (Hypothesis 9)}

Weekly Sharpe ratios were calculated from daily returns for the Russell 2000 Value Index and the Morningstar Small Value Investment Category for the period March 1, 2009 to December 31, 2017 representing 646 periods.

Appendix I shows the KS-test for normality and the F-test two-samples for variance results for the period addressed in the study. The KS-test was normal for each period; therefore, the F-test two samples for variance was conducted as identified in the study's methodology section. The F-value for the period was 1.001. The corresponding p-value for the period was 0.496 . Given these results, the null hypothesis for the time period was retained. Therefore, the actively managed small value investment category Sharpe ratio was not significantly greater than the passively managed Russell 2000 Value Index Sharpe ratio for the time period.

\section{CONCLUSION}

The current bull market has become the longest running in history (Mackintosh, 2018). Previous to the record, investors have been slowing their appetite for passive funds as inflows to these funds were down $44 \%$ for 2018 compared to the same period last year. At the same time, actively managed funds net outflows have been more than $\$ 500$ billion since 2015 and approximately $\$ 29$ billion for the first six months of the year (Baer \& Sun, 2018).

Given the fear of the investors looking for a market top, the findings of the study and the previous research, investors may want to consider diversification between actively managed funds and index funds. This diversification should however consider the associated risk with any given investment.

Further implications of the study indicate that mutual fund managers may be able to justify the higher expense ratios required to run active funds based on the higher risk-adjusted returns given the market volatility and potential falling indexes. Investors, however, should carefully review fund expenditures to ensure the fees are minimal and closely resemble those charged by an index fund. If the fees charged by 
active funds are too high relative to an index fund, the less chance an investor will have to beat the index given the net return of the fund.

This study found that on a risk-adjusted basis in the nine hypotheses tested the mean daily Sharpe Ratios per week were not significantly higher for the active indices (proxies for active management) as compared to the passive indices (proxies for passive management). The mean daily Sharpe Ratios per week were higher for the Small Growth Category versus the Russell 2000 Growth Index, the Small Blend Category versus the Russell 2000 Index, the Large Value Category versus the Russell 1000 Value Index, and the Small Value Category versus the Russell 2000 Value Index. For all the remaining categories the passive indices mean daily Sharpe Ratios were higher.

The findings of this study added to the continued debate of active versus passive mutual fund management. Active managers will have to provide excess returns to justify the higher management fees. Given the fact that anomalies have shown to shift over time in the Morningstar fund categories and other investment groups when compared to their benchmark index, continued research is warranted (Prondzinski, 2010). The identification of these trends will validate active management fees and serve as an advantage for the individual to invest in funds that have the opportunity to generate excess returns above the corresponding index.

\section{REFERENCES}

Abrantes, A. (2017, August 25). Active versus Passive Management. Wealth Management. Baer, J., \& Sun, M. (2018, July 14.) Low-Cost Index Funds Are Losing Their Allure. Wall Street Journal. Blitz, D. (2014). The Dark Side of Passive Investing. The Journal of Portfolio Management, Fall, 41, 1.

Bogle, J. (2018, May 21). Bogle's Battle. Barron's.

Clift, T. (2016, August). Modern Investing Trends Reframe Active vs. Passive Debate. Journal of Financial Planning.

Ellis, C. D. (2015, July/August). In Defense of Active Investing. Financial Analysts Journal.

Fuller, R. J., Han, B., \&, Tung, Y. (2010). Thinking About Indices and "Passive" Versus Active Management. The Journal of Portfolio Management, Summer.

Jones, R. C., \& Wermers, R. (2011). Active Management in Mostly Efficient Markets. Financial Analysts Journal, 67(6).

Mackintosh, J. (2018, August 23). Sorry for Quibble, but This Record Is Bull. Wall Street Journal.

Malkiel, B. (2017, June 6). Index Funds Still Beat 'Active" Portfolio Management. Wall Street Journal.

Miller, M. (2006). Active versus passive investing: Evidence from 1995-2002 market cycle. Retrieved from Dissertations and Theses database. (AAT 3205544)

Morningstar. (2018). Fact Sheet: The Morningstar Style Box. Retrieved August 23, 2018, from https://corporate.morningstar.com/US/documents/MethodolgyDocuments/FactSheets/Morningsta rStyleBox_FactSheet_pdf.

Prondzinski, D. (2010). Passive versus active management of mutual funds: Evidence from the 1995-2008 period (Order No. 3404491). Available from ProQuest Central. (516280447). Retrieved from http://search.proquest.com.proxy.davenport.edu/docview/516280447?accountid=40195. 


\section{APPENDIX A}

F-Test Two-Sample for Variances

\begin{tabular}{lrr}
\hline & Variable 1 & \multicolumn{1}{c}{ Variable 2 } \\
\hline Mean & 0.12228431 & 0.136861235 \\
Variance & 0.261945222 & 0.266301296 \\
Observations & 646 & 646 \\
df & 645 & 645 \\
F & 0.983642311 & \\
P $(\mathrm{F}<=\mathrm{f})$ one-tail & 0.41708666 & \\
F Critical one-tail & 0.878422468 & \\
\hline
\end{tabular}

One-Sample Kolmogorov-Smirnov Test

$\mathrm{N}$

LargeGrowth Russell1000Growth

Normal Parameters a,b

Mean

646

646

Std. Deviation

0.1223

0.1369

Most Extreme Differences

Absolute

0.51181

0.51604

0.031

0.034

Positive

0.023

0.021

Negative

$-0.031$

$-0.034$

Test Statistic

0.031

0.034

Asymp. Sig. (2-tailed)

$.190 \mathrm{c}$

$.074 \mathrm{c}$

a Test distribution is Normal.

$b$ Calculated from data.

c Lilliefors Significance Correction. 


\section{APPENDIX B}

F-Test Two-Sample for Variances

\begin{tabular}{lrr}
\hline & Variable 1 & \multicolumn{1}{c}{ Variable 2 } \\
\hline Mean & 0.115772765 & 0.129188515 \\
Variance & 0.262464502 & 0.26268243 \\
Observations & 646 & 646 \\
df & 645 & 645 \\
$\mathrm{~F}$ & 0.999170377 & \\
$\mathrm{P}(\mathrm{F}<=\mathrm{f})$ one-tail & 0.495797146 & \\
$\mathrm{~F}$ Critical one-tail & 0.878422468 & \\
\hline
\end{tabular}

One-Sample Kolmogorov-Smirnov Test

$\mathrm{N}$

MidcapGrowth RussellMidcapGrowth

$646 \quad 646$

Normal Parametersa,b Mean

$0.1158 \quad 0.1292$

Std. Deviation

0.51231

0.51253

Most Extreme Differences

Absolute

0.031

0.033

Positive

0.016

0.018

Negative

$-0.031$

$-0.033$

Test Statistic

0.031

0.033

Asymp. Sig. (2-tailed)

$.195 \mathrm{c}$

$.087 \mathrm{c}$

a Test distribution is Normal.

b Calculated from data.

c Lilliefors Significance Correction. 


\section{APPENDIX C}

F-Test Two-Sample for Variances

\begin{tabular}{lrr}
\hline & Variable 1 & Variable 2 \\
\hline Mean & 0.108467837 & 0.105822796 \\
Variance & 0.276719801 & 0.268313393 \\
Observations & 646 & 646 \\
df & 645 & 645 \\
$\mathrm{~F}$ & 1.031330557 & \\
$\mathrm{P}(\mathrm{F}<=\mathrm{f})$ one-tail & 0.347682825 & \\
$\mathrm{~F} \mathrm{Critical} \mathrm{one-tail}$ & 1.138404398 & \\
\hline
\end{tabular}

One-Sample Kolmogorov-Smirnov Test

$\mathrm{N}$

SmallGrowth Russell2000Growth

Mean

646

646

Normal Parametersa,b

Std. Deviation

0.1085

0.1058

Most Extreme Differences

Absolute

0.52604

0.51799

0.023

0.023

Positive

0.019

0.02

Negative

$-0.023$

$-0.023$

Test Statistic

0.023

0.023

Asymp. Sig. (2-tailed)

$.200 \mathrm{c}, \mathrm{d}$

$.200 \mathrm{c}, \mathrm{d}$

a Test distribution is Normal.

$\mathrm{b}$ Calculated from data.

c Lilliefors Significance Correction.

$\mathrm{d}$ This is a lower bound of the true significance. 


\section{APPENDIX D}

F-Test Two-Sample for Variances

\begin{tabular}{lrr}
\hline & Variable 1 & \multicolumn{1}{c}{ Variable 2 } \\
\hline Mean & 0.118700392 & 0.125898873 \\
Variance & 0.254025037 & 0.253585099 \\
Observations & 646 & 646 \\
df & 645 & 645 \\
$\mathrm{~F}$ & 1.001734872 & \\
$\mathrm{P}(\mathrm{F}<=\mathrm{f})$ one-tail & 0.491222971 & \\
$\mathrm{~F}$ Critical one-tail & 1.138404398 & \\
\hline
\end{tabular}

One-Sample Kolmogorov-Smirnov Test

$\mathrm{N}$

$\begin{array}{rr}\text { LargeBlend } & \text { Russell1000 } \\ 646 & 646\end{array}$

Normal Parametersa, $b$

Mean

0.1187

0.1259

Most Extreme Differences

Std. Deviation

0.50401

0.50357

Absolute

0.042

Positive

0.038

0.026

Negative

0.026

$-0.042$

Test Statistic

$-0.038$

0.042

Asymp. Sig. (2-tailed)

0.038

$.008 \mathrm{c}$

a Test distribution is Normal.

$.028 \mathrm{c}$

b Calculated from data.

c Lilliefors Significance Correction. 


\section{APPENDIX E}

F-Test Two-Sample for Variances

\begin{tabular}{lrr}
\hline & Variable 1 & \multicolumn{1}{c}{ Variable 2 } \\
\hline Mean & 0.113572117 & 0.123473176 \\
Variance & 0.268161187 & 0.264191416 \\
Observations & 646 & 646 \\
df & 645 & 645 \\
$\mathrm{~F}$ & 1.015026116 & \\
$\mathrm{P}(\mathrm{F}<=\mathrm{f})$ one-tail & 0.424923211 & \\
$\mathrm{~F} \mathrm{Critical} \mathrm{one-tail}$ & 1.138404398 & \\
\hline
\end{tabular}

One-Sample Kolmogorov-Smirnov Test

$\mathrm{N}$

MidCapBlend RussellMidCap

$646 \quad 646$

Normal Parametersa,b

Mean

0.1136

0.1235

Std. Deviation

0.51784

0.514

Most Extreme Differences

Absolute

0.034

0.041

Positive

0.022

0.022

Negative

$-0.034$

$-0.041$

Test Statistic

0.034

0.041

Asymp. Sig. (2-tailed)

$.075 \mathrm{c}$

$.013 \mathrm{c}$

a Test distribution is Normal.

b Calculated from data.

c Lilliefors Significance Correction. 


\section{APPENDIX F}

F-Test Two-Sample for Variances

\begin{tabular}{lrr}
\hline & Variable 1 & \multicolumn{1}{c}{ Variable 2 } \\
\hline Mean & 0.102427924 & 0.100540542 \\
Variance & 0.271446476 & 0.268198187 \\
Observations & 646 & 646 \\
df & 645 & 645 \\
$\mathrm{~F}$ & 1.012111524 & \\
$\mathrm{P}(\mathrm{F}<=\mathrm{f})$ one-tail & 0.439272609 & \\
$\mathrm{~F} \mathrm{Critical} \mathrm{one-tail}$ & 1.138404398 & \\
\hline
\end{tabular}

One-Sample Kolmogorov-Smirnov Test

$\mathrm{N}$

Normal Parametersa,b

Most Extreme Differences

Test Statistic

Asymp. Sig. (2-tailed)

a Test distribution is Normal.

b Calculated from data.

c Lilliefors Significance Correction.

$\mathrm{d}$ This is a lower bound of the true significance.
SmallBlend Russell2000

$646 \quad 646$

Mean

Std. Deviation

0.1024

0.1005

$0.52101 \quad 0.51788$

$0.026 \quad 0.021$

$0.024 \quad 0.021$

$\begin{array}{ll}-0.026 & -0.017\end{array}$

$0.026 \quad 0.021$

$.200 \mathrm{c}, \mathrm{d} \quad .200 \mathrm{c}, \mathrm{d}$ 


\section{APPENDIX G}

F-Test Two-Sample for Variances

\begin{tabular}{lrr}
\hline & Variable 1 & \multicolumn{1}{c}{ Variable 2 } \\
\hline Mean & 0.110701617 & 0.107712854 \\
Variance & 0.254625865 & 0.25015898 \\
Observations & 646 & 646 \\
df & 645 & 645 \\
$\mathrm{~F}$ & 1.017856184 & \\
$\mathrm{P}(\mathrm{F}<=\mathrm{f})$ one-tail & 0.411123359 & \\
$\mathrm{~F} \mathrm{Critical} \mathrm{one-tail}$ & 1.138404398 & \\
\hline
\end{tabular}

One-Sample Kolmogorov-Smirnov Test

$\mathrm{N}$

\section{LargeValue Russell1000Value}

$646 \quad 646$

Normal Parametersa,b

Mean

0.1107

0.1077

Std. Deviation

0.5046

0.029

0.50016

Absolute

0.026

0.035

Positive

$-0.029$

0.029

Negative

0.029

$.200 \mathrm{c}, \mathrm{d}$
$-0.035$

0.035

$.055 \mathrm{c}$
Asymp. Sig. (2-tailed)

a Test distribution is Normal.

$\mathrm{b}$ Calculated from data.

c Lilliefors Significance Correction.

$\mathrm{d}$ This is a lower bound of the true significance. 


\section{APPENDIX H}

F-Test Two-Sample for Variances

\begin{tabular}{lrr}
\hline & Variable 1 & \multicolumn{1}{c}{ Variable 2 } \\
\hline Mean & 0.11122562 & 0.114632 \\
Variance & 0.272292228 & 0.270581453 \\
Observations & 646 & 646 \\
df & 645 & 645 \\
$\mathrm{~F}$ & 1.006322587 & \\
$\mathrm{P}(\mathrm{F}<=\mathrm{f})$ one-tail & 0.468117406 & \\
$\mathrm{~F}$ Critical one-tail & 1.138404398 & \\
\hline
\end{tabular}

One-Sample Kolmogorov-Smirnov Test

$\mathrm{N}$

MidCapValue RussellMidCapValue

$646 \quad 646$

Normal Parametersa,b Mean

Std. Deviation

0.1112

0.1146

Most Extreme Differences

Absolute

0.52182

0.52017

Positive

0.027

0.025

Negative

0.027

0.025

$-0.024$

$-0.02$

Test Statistic

0.027

0.025

Asymp. Sig. (2-tailed)

$.200 \mathrm{c}, \mathrm{d}$

$.200 \mathrm{c}, \mathrm{d}$

a Test distribution is Normal.

b Calculated from data.

c Lilliefors Significance Correction.

$\mathrm{d}$ This is a lower bound of the true significance. 


\section{APPENDIX I}

F-Test Two-Sample for Variances

\begin{tabular}{lrr}
\hline & Variable 1 & \multicolumn{1}{c}{ Variable 2 } \\
\hline Mean & 0.096490503 & 0.091408395 \\
Variance & 0.271817983 & 0.271613089 \\
Observations & 646 & 646 \\
df & 645 & 645 \\
F & 1.00075436 & \\
$\mathrm{P}(\mathrm{F}<=\mathrm{f})$ one-tail & 0.496181437 & \\
$\mathrm{~F}$ Critical one-tail & 1.138404398 & \\
\hline
\end{tabular}

One-Sample Kolmogorov-Smirnov Test

$\mathrm{N}$

Normal Parametersa,b

Most Extreme Differences

Test Statistic

Asymp. Sig. (2-tailed)

a Test distribution is Normal.

$\mathrm{b}$ Calculated from data.

c Lilliefors Significance Correction.

$\mathrm{d}$ This is a lower bound of the true significance.

Mean

Std. Deviation

Absolute

Positive

Negative

$\begin{array}{rr}\text { SmallValue } & \text { Russell2000Value } \\ 646 & 646 \\ 0.0965 & 0.0914 \\ 0.52136 & 0.52117 \\ 0.024 & 0.015 \\ 0.024 & 0.015 \\ -0.018 & -0.013 \\ 0.024 & 0.015 \\ .200 \mathrm{c}, \mathrm{d} & .200 \mathrm{c}, \mathrm{d}\end{array}$

646

52117

0.015

0.015

0.015

$200 \mathrm{c}, \mathrm{d}$ 